Jan W. Żelazny

Pontifical University of John Paul II in Krakow

\title{
The tradition of St. Thomas' mission to India in the light of patristic sources
}

The Church tradition calls the followers of Christ in India Saint Thomas Christians. Where does this designation come from and why is it connected with the name of one of the Apostles of Christ?

Taking into account the extant records, it seems that the appearance of Christ's disciples in India was formerly associated with another Apostle, St. Bartholomew. According to Ecclesiastical History written by Eusebius of Caesarea, the hypothetical founder of the Catechetical School of Alexandria, Pantaenus, travelled to India in the middle of the $2^{\text {nd }}$ century. Eusebius writes:

Pantaenus was one of these, and is said to have gone to India. It is reported that among persons there who knew of Christ, he found the Gospel according to Matthew, which had anticipated his own arrival. For Bartholomew, one of the apostles, had preached to them, and left with them the writing of Matthew in the Hebrew language, which they had preserved till that time. ${ }^{1}$

It is worth noting that a route alternative to the overland Silk Road, connecting China and India with the Mediterranean world, was a maritime route passing through modern Bab elMandeb Strait, referred to as Monsoon Route. It was known from the times of the Pharaohs. Through a system of junctions with the River Nile, the so-called Canal of the Pharaohs, it enabled communication with the main centres in Egypt, and through Egypt, with other countries of the Mediterranean Basin. It was a dangerous route, but nevertheless, it played an important role in commercial and cultural exchange with the Far East throughout antiquity. It was this route that, apart from the riches of Egypt itself and the lands lying behind the First Cataract, Alexandria owed its prosperity to. It also explains the presence of the Oriental concepts in the Gnostic thought of writers living in that area.

\footnotetext{
${ }^{1}$ Book V, chapter 10. 2-3.
} 
Pantaenus is believed to have met in India Christians who attributed the beginning of Gospel preaching in their country to Apostle Bartholomew. They used the Gospel of Matthew. However, one should keep in mind that the Church Fathers' grasp of geography was sometimes far from perfect. There is still no consensus among specialists as to which India Eusebius was actually referring to, since in antiquity many lands were identified with that country in the eyes of a layman. The places often pointed out in this discussion include Yemen and the Arabian Peninsula in general. Nevertheless, let us assume that the information in question indeed referred to India, i.e., the lands situated on the Indian Peninsula.

At this point, it would be of benefit to go back in reading Ecclesiastical History and explain one issue. Accounting for the origin of the Gospel of Matthew, Eusebius notes (book III, chapter 24.6):

For Matthew, who had at first preached to the Hebrews, when he was about to go to other peoples, committed his Gospel to writing in his native tongue, and thus compensated those whom he was obliged to leave for the loss of his presence.

From the statement above it can be inferred that Eusebius believed the first version of the Gospel to be written in Aramaic. Most biblical scholars agree with this account, based on arguments such as literary style replete with Semitisms and numerous Aramaic insertions in the text, as well as the whole patristic tradition. A similar opinion is expressed by St. Irenaeus in Adversus Haereses. Consequently, the copy found by Pantaenus was most probably written in what would now be called Palestinian Aramaic.

But how did an Aramaic Gospel reach India? It could have arrived there the same way Pantaenus did - by sea. If that was the case, then the Jewish diaspora in Alexandria served as a bridge for the Good News, clothed in a Semitic guise, to enter the Indian subcontinent.

It is widely assumed that the Christian community in India was initially closely linked to their fellow believers in the Roman Empire, and their communication took place along the above-mentioned maritime route. How, then, do researchers supporting this view explain the phenomenon of calling Indian Christians St. Thomas Christians and not St. Bartholomew Christians? According to them, the maritime route became very dangerous later. It was then (in the $7^{\text {th }}$ century) that the tradition of Apostle Thomas' mission to India appeared, as well as the popular placing of his tomb in Malaipur (!), Madras state. It can be explained by the influence of Syriac Christianity, closely associated with St. Thomas, which at that time reached India via overland routes and largely took control over Christian communities. The following process of Syriacization became visible especially in the liturgy of Indian Christians. It should be noted that all these considerations pertain to the Church located in southwest India. In other 
words, the tradition of St. Thomas' mission to India could be a later account, explaining not so much the beginnings of the local Church as the influence of the Assyrian Church of the East in that region as well as the dependence of its hierarchy on the Catholicos of Seleucia-Ctesiphon, and later the Catholicos of Baghdad. Consequently, it should be considered to be more of a legend legitimizing the contemporary state of affairs than a faithful rendering of the past. According to this view, the Good News first reached the Indian subcontinent via Alexandria, and only later was it subordinated to the Aramaic tradition. However, the problem seems to be more complex than that.

Aramaic (Syriac) Christianity frequently refers to the so-called St. Thomas Tradition. Its expression can be found in the texts from the $4^{\text {th }}$ century called the Thomas Collection, which include the Acts of Thomas, the Infancy Gospel of Thomas, and the Gospel of Thomas. The collection is supplemented by a selection of works related to the Edessan legend, which speaks of a correspondence between Christ and Abgar, a local potentate in Oshroene, and of a portrait of the former, and finally, the story of one of Christ's disciples, Addai, teaching in Edessa. ${ }^{2}$

All the cited texts refer to missionary activities in Mesopotamia, thousands of kilometres away from India. Nevertheless, one should keep in mind that Edessa was at that time one of the main centres of trade with the East, i.e., India and China. The Silk Road and the route via the Persian Gulf crossed exactly in that city. Consequently, the influence of other cultures in the spheres of economy, culture and religion was considerable. The first Christian at the royal court in Edessa known to us by name, Bardaisan, wrote at the beginning of the $3^{\text {rd }}$ century a dialogue titled Book of the Laws of the Countries. ${ }^{3}$ It deals with the issues of fate, freedom and nature, and also contains remarks on life and laws of India. ${ }^{4}$ His observations show no trace of fantasising and testify to good knowledge of the realities of life in the region. It proves that there existed a contact between this merchant city living from trade with the Orient and faraway lands. It is not surprising, then, that Christian missions, through Christianised Aramaic merchants, reached as far as India.

It is also known that Christian communities from the western coast of India were included in the list of bishoprics of the Assyrian Church of the East, remaining under the control of Seleucia-Ctesiphon (later Baghdad), and from the year 424 formally declaring absolute independence from the Church of the Roman Empire. A unifying factor for those communities, as well as all the Churches subordinate to the Syriac Catholicos, was the liturgical Syriac, equivalent to the Edessan dialect of Aramaic. Although Eastern Syriac differed

\footnotetext{
${ }^{2}$ See: Atti di Mar Mari, I. Ramelli (ed.) Brescia 2008.

${ }^{3}$ Bardesanes [Bardaisan], Ksiega praw narodów [Book of the Laws of the Countries], translated by. J. Woźniak CM [in:] Polska Syrologia, Warszawa 2010, 32-252.

${ }^{4}$ Ibid., 27-28 (245); 39 (248).
} 
(and differs) both in terms of speech and of writing, it can still be said there was a tradition of the Syriac language which connected the ancient Church of the Persian Empire with the communities established in India. The unity of language was followed by the unity of liturgy (practiced sacraments) and of theological tradition. As centuries passed, mainly due to the Latinizing influences discussed at today's conference, a shift of allegiance occurred, which made the Indian community follow the Syro-Orthodox Church. ${ }^{5}$ Nevertheless, the connection with what can be called the patristic Syriac tradition has remained alive. On the other hand, one of the oldest documents of Syriac Christianity, the Acts of Thomas, suggests that still another hypothesis could be true.

The above-mentioned Acts of Thomas was written at the beginning of the $3^{\text {rd }}$ century, most probably in Edessa. St. Ephrem attests that it was at that time, in the circles of Bardaisan, that the apocryphal Acts came into existence. The text is one of the oldest apocryphal sources belonging to the so-called Acts of the Apostles. Whether it was written by the Gnostics, as St. Ephrem suggests, or in the orthodox circles, still remains a subject of debate. However, it is not significant in terms of looking at the patristic sources of the tradition of St. Thomas' mission to India. In its factual layer, the Acts presents the beginnings of Christianity in India, associating them with the decision of Jesus himself! ${ }^{6}$ He was supposed to... sell Apostle Thomas to an Indian merchant and thus sent him on a mission trip. This is how the Acts renders this story:

At that season all we the apostles were at Jerusalem, Simon who is called Peter and Andrew his brother, James the son of Zebedee and John his brother, Philip and Bartholomew, Thomas and Matthew the publican, James the son of Alphaeus and Simon the Canaanite, and Judas the brother of James: and we divided the regions of the world, that every one of us should go unto the region that fell to him and unto the nation whereunto the Lord sent him.

According to the lot, therefore, India fell unto Judas Thomas, which is also the twin: but he would not go, saying that by reason of the weakness of the flesh he could not travel, and 'I am an Hebrew man; how can I go amongst the Indians and preach the truth?'

Seeing the Apostle's hesitation, the Lord did not so much convince him as made him face the facts. The narrator recounts that Christ met the merchant Habban, who was looking for a gifted carpenter. Habban was ordered by King Gudnafar to buy such a slave. King Gudnafar was a historical figure. There are

\footnotetext{
${ }^{5}$ In antiquity the head of the Syro-Orthodox Church was the so-called Maphraian from Takrit. However, as a result of the Arab invasion, also Roman territories which were under the headship of the patriarchal capital in Antioch fell under the rule of the new masters. Consequently, it was the patriarchs of Antioch that took control over the whole church community adhering to the tradition of the Monophysites and St. Cyril. Today, nevertheless, in order to emphasize the independence of the Indian Church, the title of maphraian has been reinstated and given to the head of Christians in India, to distinguish him from the patriarch of Antioch.

${ }^{6}$ This gave a stimulus for the evolution of a theory, popular in the $19^{\text {th }}$ century, that Jesus himself was a disciple of Brahmins (!).
} 
coins and inscriptions of his name, along with the name of his brother, Gad, dating back to the $1^{\text {st }}$ century. They reigned in north-western India. That region was known for its numerous contacts with the Greek world. ${ }^{7}$ From the times of Alexander the Great and the Greek kingdoms of Bactria and Indus Valley, the communication between that part of India and the Mediterranean world was well-established. Although the contacts may not have been particularly lively they were constant. As mentioned above, the ruler cited in the Acts, during whose reign the mission of St. Thomas to India was supposed to take place, was a historical figure, steeped in the realities of the period. ${ }^{8}$ The order to buy a craftsman was also nothing strange in itself. What was shocking was the fact that the object of trade was Judas Thomas, and that he was sold by Jesus himself. What makes the story a little less offending is that Jesus did not keep the money (30 silver coins!) but gave it all to Thomas.

The remainder of the apocrypha describes the Apostle's adventures at the royal court. It consists of 13 episodes reporting events connected with the missionary activity of Thomas, who after working as a royal architect (building a heavenly palace for the king), travelled to different countries in the Indian Peninsula, preaching the Gospel. He became known to public as a miracle worker, physician and magician freeing people from the bonds of evil spirits.

His missionary activity is accompanied by both opposition on the part of the authorities and manifestations of God's power in the form of miracles and conversions. Despite initial conversions of rulers, the resentment of the upper strata is constantly emphasized. However, it remains unclear to what extent is it just a literary topos prevalent in this kind of literature. What meets with fiercest opposition is the Apostle's teaching on preserving purity by the baptized. It seems to be the biggest stumbling block and at the same time it is the clearest indication of this text originating in the Gnostic circles. It may be also seen as an element undermining the credibility of this account since preaching asceticism in the Indian subcontinent should not be perceived as strange. It might have met with reluctance but it was nothing unusual. In the last episode (13) Thomas is sentenced to death for teaching what is against human nature. King Mazdai, nevertheless, had no doubts as to the power that accompanied the Apostle. Therefore, after having Thomas killed and buried, he used the relics from the Apostle's tomb to heal his own son.

It is not time and place to reflect upon the theological interpretation of the recorded songs and prayers of St. Thomas. Still it is worth noting that the text contains older fragments, such as the Hymn of the Pearl. Nevertheless, what is of interest to us is one thing. After the arrival of Thomas at Gudnafar's court

\footnotetext{
${ }^{7}$ See: S. Kalita, Grecy w Baktrii $i$ w Indiach [Greeks in Bactria and India], Kraków 2005; cf. M. Mitchinger Undo - Greek and Indo Scythian coin - age, London 1975-1976.

${ }^{8}$ A.-J. Festugiére, Les Actes apocryphes de Jean et de Thomas, Genève 1983, 45.
} 
there are no clear indications as to the subsequent direction of the Apostle's mission. All we know is that it was somewhere in India. It seems logical, taking into consideration the scope of territory in question, that the Apostle's mission, if it actually took place, was contained to northwest India, extending to the Indus Valley and the western coast at the most. There is no evidence that it reached the territory that would later become the missionary field of the Malabar Church. The Christianization of those areas should be rather attributed to the Apostle's disciples, natives of the land, who would most certainly refer to their founder.

The above data can be reconciled with the information passed by Eusebius, which in this context can be seen as an argument supporting this version of the route along which the new faith expanded. As was noted before, the Gospel found by Pantaenus was most probably written in Aramaic. Was it then that the missionaries of Alexandria upon arriving in India found out there were already fellow brethren there, who had brought the Good News to the subcontinent before? That those Christians were in possession of an Aramaic Gospel was only logical since Aramaic was the language of the first Apostles in the area. The fact that it belonged to Jewish missionaries was obvious as well. All in all, it was addressed to Jews, also Jews from the biggest diaspora, i.e., Babylonian Jews. The missionaries following St. Thomas might have brought such a text along. There is evidence of Greek-Aramaic inscriptions in that area. ${ }^{9}$ Although from the turn of the $3^{\text {rd }}$ century the four separate Gospels (Matthew, Mark, Luke and John) were replaced in this language circle with Diatessaron, still the presence of an Aramaic Gospel of Matthew in the initial stage of missionary movement seems plausible and is taken seriously by researchers. Only minor linguistic differences and similar mentality could have contributed to the popularity of this Gospel among Syriac Christians of the time.

Researchers emphasize that the Semitic tradition is characterised by high resistance to change and inherent conservatism. A once established standard of the Holy Scriptures had chances of surviving for years. In the Empire Christians were using four Gospels and here - to Pantaenus' astonishment - he found something that might have appeared to him as somewhat archaic.

One more detail worth noting is that Pantaenus was someone new. He was surprised to find fellow brethren or an Aramaic version of the Gospel of Matthew. Maybe then the maritime route was not as popular among the preachers of the Good News as it might seem? The astonishment of Pantaenus and subsequent records of his account are somewhat puzzling. Was it that this road was not how the Gospel reached the Indian subcontinent?

Why was then the mission of St. Bartholomew and his martyr death mentioned in the text? Is it a parallel tradition or maybe the Apostles embarked on the

\footnotetext{
${ }^{9}$ D. Schlumberg, Une bilingue gréco - araménne d'Açoka, "Journal Asiatique" 1-48.
} 
journey together and one of them (Thomas) settled in Mesopotamia while the other arrived as far as in India? They brought the Gospel in an Aramaic guise. Since later on it was associated with the Thomas Tradition, was the work of Bartholomew attributed to Thomas? It is just one of the hypotheses.

There is yet another possibility. Maybe a two-way Christianization took place. On the one hand, there was the Alexandrian missionary direction, connected with the person of St. Bartholomew, and on the other hand, the Syriac tradition of St. Thomas, which through commercial contacts affected mostly the north of the country. Both directions, one from the south and one from the north, provided missionaries who reached the territory of India. At the time there were no tensions between them though differences were easily discernible. Thus the mission might have occurred simultaneously and the communities coexisted alongside. When the contacts were breached on the part of the south, a new situation emerged. The Church of the East was becoming better and better organised and its influence was far-reaching. A good organisation enabled it to widen its sphere of influence on church communities. Despite some tensions, a Church identifying itself with the Parthian state could count on benevolence of its representatives regardless of their convictions. It is also visible in the so-called Nestorian mission in China. The same mechanism was at work during the pontificate of Catholicos Timothy at the turn of the $9^{\text {th }}$ century. If it had functioned earlier than that, then it could have accounted for the gradual Syriacization of Indian Christians. Their reference to St. Thomas seems obvious - and that is how the notion of St. Thomas Christians was born in the minds of the congregation. The capital city of Edessa remained outside the boundaries of the Parthian Empire and consequently, there was no need to locate the tomb of the Apostle in the capital of a Roman province. On the contrary, moving it to faraway India seemed to be a more desirable solution. Such a decision would not only justify the apostolicity of the area, but also its connection to the Church in Seleucia and Ctesiphon.

Finally, it can be seen from the apocryphal account that the Gospel had its greatest impact on the upper classes, and not the poorest, as propaganda would have it. The people converted by St. Thomas were soldiers, yet not ordinary soldiers, but rather commanders, such as Sifar - let us call them generals, royal officials and members of the royal family - the king's son, Wizan, and queen Tertia. These are all people from the upper strata of the society, who had contacts both with travellers and merchants. It is them that St. Thomas was addressing his sermons to. Crowds of people from the kingdoms visited by the Apostle listened to his sermons, but in fact, he only spoke to the chosen ones. An average citizen was merely a witness of his teaching. And although the text speaks of numerous conversions, it seems to be a purely conventional rhetorical device, typical of such situations. Since it was an Apostle that preached the Gospel, then it had to 
be confirmed by God with miracles and spectacular conversions. They should be big, both in terms of kind and number. Meanwhile the converts gathered for prayer in small groups; there are no descriptions of spacious halls or special places of gathering. In other words, according to the text, the converts were many, but in reality they were nowhere to be seen. This poses further questions. How could such Christianity have survived? Looking at its later history, it was connected with the local populace. Therefore, there must have been a point in time when a kind of popular mission took place though there is no mention of it in the discussed sources. Maybe it was then that the legend of Apostle Thomas came into being, explaining the origin of Christianity in India. It did not have to be a perfect record of the past since no one at that time paid attention to such details. If something was believed to have its origin in a certain event, then a primary cause could be treated as a subsequent one. Devoid of regular contacts with its mother centres of evangelism, the Indian Christians from the southwest part of the subcontinent referred to their own tradition established in the Church through their isolation from other Christian communities. That is how the Gospel of Matthew in Aramaic survived in their fellowship.

To sum up, it is clearly visible how strong the relationship between the Christianization process in India and Syriac Christianity was. Although in the light of currently accessible sources it is not possible to unequivocally decide via which route the first Christians arrived in India, nevertheless, some documents indicate that among the first missionaries there were representatives of Aramaic Christianity. The territories which are traditionally believed to have been the field of missionary work of the Apostle Thomas must have had some kind of preparatio evangelica through the Greek kingdoms located in northwest India. In the course of historical transformations, the Syriac element, owing to its political and geographical conditionings, gained advantage among the Christian communities in that region, which was further strengthened by a long-term loss of direct contacts between Europe and India. The fact of being a minority made Indian Christians search for support among fellow believers outside of their country. The closest and strongest in the $5^{\text {th }}-6^{\text {th }}$ centuries was the Assyrian Church. Thus the Syriac tradition gained in strength and was able to assimilate other influences. This explains its domination in the liturgy and displacing other customs. All in all, the patristic sources confirm the accuracy of referring to St. Thomas Tradition in the Indian Churches. 